diseases of children and their prevention; and at a press conference last week the organisers stressed the need for outside finance when Government expenditure is coming under restraint. Further details are available from the Appeal Office, Institute of Child Health, 30 Guilford Street, London WC1.

\section{Kidney transplants}

The number of kidney transplants performed in Great Britain and Eire was 59 in November. The number of patients awaiting transplant at the end of the month was 1113

\section{BMA committees meet}

The Organisation Committee met on 21 October and re-elected Dr R A A R Lawrence, a general practitioner from Derby, as chairman. The committee discussed recruitment and how the BMA could be better represented in hospitals. This matter has been referred to the Status of the Association Working Party.

Dr J C Graham (London) is chairman for another session of the Occupational Health Committee. Meeting on 20 October it received comments from members on the DHSS draft circular on occupational health services for NHS staff. The service will be "separate and distinct from the general framework of primary and secondary health services provided under the NHS Acts" which the committee welcomed, but one member pointed out that the BMA policy for a national occupational health service under the DHSS seemed as far away as ever.

\section{University of Otago}

Dr $\mathbf{R} \mathbf{H}$ Johnson has been appointed dean and professor of medicine at the new clinical medical school in Wellington, New Zealand. Dr Johnson graduated from Cambridge in 1958, and after house appointments in London and Oxford joined the University Department of Neurology at Oxford. In $1968 \mathrm{Dr}$ Johnson was appointed senior lecturer in neurology in the University of Glasgow at the Western Infirmary, and later at the Institute of Neurological Sciences and Victoria Infirmary. In 1974 he was visiting professor at the Montreal Neurological Institute. Dr Johnson's main research interests include disorders of the autonomic nervous system, the physiology of exercise, and epilepsy.

\section{COMING EVENTS}

Institute of Dermatology-Details of the programme of lectures for part of the University of London Diploma Course in Dermatology spring term are now available from the Institute, St John's Hospital for Diseases of the Skin, Lisle Street, Leicester Square, London WC2H 7BJ. (Tel 01-437 8383.)

Institute of Orthopaedics-Details of the course of lectures on surgery of the upper limb, January to March, are now available from the Institute, Royal National Orthopaedic Hospital, 234 Great Portland Street, London W1N 6AD.

Royal Society-Details of the programme January to March are now available from the Executive Secretary, Royal Society, 6 Carlton House Terrace, London SW1Y 5AG. (Tel 01-839 5561 ext 278.)

\section{SOCIETIES AND LECTURES}

For attending lectures marked * a fee is charged or a ticket is required. Applications should be made first to the institution concerned.

Tuesday, 21 December

INSTITUTE OF UROLOGY $-4.30 \mathrm{pm}$, special guest lecture by Dr Bruce Stewart (USA): Whole body scanning in urology.

\section{BMA NOTICES}

\section{Diary of Central Meetings}

\section{DECEMBER}

21 Tues Medical Teachers and Research Workers

21 Tues Scottish General Medical Services Committee ( 7 Drumsheugh Gardens, Edinburgh) $10.30 \mathrm{am}$

22 Wed Council, 10 am 30 Thurs Scottish Council (9 Drumsheugh Gardens,
Edinburgh), 10.45 am.

JANUARY

5 Tues Negotiating Subcommittee (CCHMS), 10 6 Wed Central Committee for Hospital Medical $12 \mathrm{wed}$ Council, $10 \mathrm{am}$. 12 Wed Council, 10 am. of Psychiatrists, 17 Belgrave Square, London
SW, $9.30 \mathrm{am}$.

20 Thurs General Medical Services Committee, 10 am.

\section{Division Meetings to be Held}

Members proposing to attend meetings marked * are asked to notify in advance the honorary secretary

Bradford and Airedale-At Bradford Royal Infirmary, Tuesday, 21 December, $8.30 \mathrm{pm}$, joint clinical

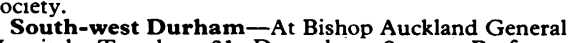
Hospital, Tuesday, 21 December, $8 \mathrm{pm}$, Professo J T Owen: "Recent advances in immunology." Tuesday, 21 December, $8.15 \mathrm{pm}$, general meeting to elect representatives for ARM.

\section{UNIVERSITIES AND COLLEGES}

MANCHESTER

MD-M C Wilson.

ROYAL COLLEGES OF PHYSICIANS OF THE UNITED KINGDOM

The following candidates were elected Members in November: A M Abdul Kareem, Sheila A Adam, M J
Agass, O M Ahmed-Taha, T Akhtar, F S S Al-Ani, Agass, O M Ahmed-Taha, T Akhtar, F S S Al-Ani,
A S Al-Atraqchi, F N Al-Azawi, O K Al-Baghdadi,
A M Al-Chalabi, A El-K Ali, R A J Al-Kaabi, Q A A M Al-Chalabi, A El-K Ali, R A J Al-Kaabi, Q A Arnold, J V Aryasingha, A A Ategbole, J H G Atherstone, R D Barber, A N Barnouti, A J Batchelor, A G Bird, Ann M Blackburn, D R Blake, W A H Bodger, D Q Borsey, R M Boyle, Elizabeth A
Braidwood, S M Breathnach, R P Brettle, A E Briggs,
A J Brown, M J Brown, J A Bullen, J H Burness, T S A J Brown, M J Brown, J A Bullen, J H Burness, T S Callaghan, A J Carless, J A Carnie, Dianne P Carter, Cheung, P-N-S Chitson, S C Chiu, G Choi Kin, C P
Chua, C J Clark, Vicky V Clement-Jones, I Cobden, Chua, C J Clark, Vicky V Clement-Jones, I Cooben, J Cohen, B M Conway, S Cook, R J Coppen,
W M Couriel, M D Cowan, Elizabeth A M Cowden, Dancy, T J David, N O Davidson, G A C De Silva,
F D Doghmi, R C Donmall, Kathryn E Dowey, G K $F$ S Doghmi, R C Donmall, Kathryn E Dowey, G K
Duckett, P A Dufton, Elizabeth C Dunn, M K Dutt, Alison R C Earley, M Edwards, I A El Hag, S M El-Hag, A T El-H Elidrissy, D A C Elliman, J A Evans, W J K F Fitzpatrick, I R Fletcher, J N Fordham, P J G Forster, J G Freeman, J F P Garnett, B J Gatus, Vanessa A L Graham, D W R Gray, S A Greene, A J Grieve, R J Grieve, K L Gupta, J P Halsey, Hayden, S H Hegde, T R Henderson, $G$ J L Hewitt, Horrocks, C W Howard, I S Hughes, $P$ W Ind, $E$ G Iwuagwu, D M De S Jayasinghe, D A Jeffs, P Jenkins, Kaldas, D P Kar, A M Karnik, M Karthigasu, B J Angela K K Kirby, $P$ J Kiernan, Jennifer A Kilvert, Angela Litt, Ann Lawson, M F Leahy, T K Lee, W Lenney,
J L Leopold, F J Lips, D R Lloyd, J P Long, D Ludwin, C J McCallum, D M McCarthy, D Macintyre McKenna, R D McKenzie, A D Macnair, A W McNinch, $R$ C McWilliam, J M Mahood, M M Malla,
$A$ R Manhire, I $H$ Manifold, M R Masser, G L
Mastaglia, P M Mathew, T M Mathew, C M Meenakshi Sundaram, H C Middleton, J A Miller, K J Misch Mohiuddin, M G Molloy, G W Morgan, A J R Morris, J W Muir, M F Murphy, H M I Nazer, R A Nesbit C Newland, Catherine $\mathrm{Ng}$ Mui Nam, Helen $M$ Nutbeam, Anne F Nutter, A Oakhill, J P J O'Connell, B P Malley, J R Owen, N E Parker, K G Patterson, $J$ N Patton, A J Peacock, Jennifer J Pearce, $R$ Peppiatt, E Phillips, W G Pickering, T A Pierscianowsk D A Raper, K W Rassam, U B Rassam, B M Reynolds, P A F Riley, J K A Roberts, P J Roberts-Thomson,

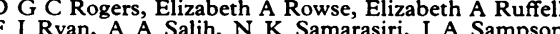
P S Sankarapandian, M A Sankoh, D J Scott, G A Sekoni, S M Z A Siddiqi, G S Q Silva, C Sirinavin, M B Skidmore, R R Slade, A G Smith, Mary J Smith, M I. Smith, Elizabeth A Smout, D G Spence, $R$ G Spencer-Jones, N Sreeharan, T G Staunton, C R Steer, W P Stephens, Georgina H Stewart, $S$ N Sullivan, Sundaralingham, R Suri, C M Tait, Adele Tan Guat Kean, Tan Tiong Har, The Hon $R$ S Tedder, T A Timmis, Ting Hoon Chin, Gladys $M$ Tinker $B$ Tomlinson, A S Torode, Catherine $S$ Trewby, D J Verster-Cohen, D T Wade, J P H Wade, $G$ S Walford,
Angela $M$ Walker, $P$ W Warren, A $M$ Weindling, R L Wijenayake, L $M$ Wijesuriya, $M$ A Wijesuriya, A A Williams, R A Williams, T H C Williams, $P$ T C $M$ Wong, D O Wood, I R Wood, Victoria $M$ Yates, T Zaniewski.

\section{Corrections}

Adrenal aldosterone-producing adenoma: use of colonic potential in diagnosis and subtraction scanning technique for localisation

In the article by $\mathrm{K} \mathrm{E}$ Britton and others ( 3 July, p 11), the second word of the summary was incorrectly printed. This should have read: "hyperaldosteronism."

\section{Mercy killing and the law}

Footnote 1 to the Medicolegal article (27 November, p 1333) should have read "Under section 2 of the Homicide Act 1957 diminished responsibility exists where the accused was suffering 'from such abnormality of mind (whether arising from a condition of arrested or retarded development of mind or inherent causes or induced by disease or injury) as substantially impairs his responsibility for his acts or omissions in doing or being a party to the killing."'

Changed levels of endogenous sex steroids in women on oral contraceptives

We regret that an error occurred in the article by Dr J M Kjeld and others (4 December, p 1354). In the table the urinary excretion values are given in $\mathrm{pmol} / 24 \mathrm{~h}$ not nmol/24 $\mathrm{h}$, and the conversion factors in the footnote should therefore read: Urinary testosterone: $1 \mathrm{pmol} / 24 \mathrm{~h} \approx 288 \mathrm{pg} / 24 \mathrm{~h}$. Urinary dihydrotestosterone: $1 \mathrm{pmol} / 24 \mathrm{~h} \approx 290$ $\mathrm{pg} / 24 \mathrm{~h}$. Urinary oestradiol: $1 \mathrm{pmol} / 24 \mathrm{~h} \approx 270 \mathrm{pg}$ $24 \mathrm{~h}$

\section{Notice to authors}

When original articles and letters for publication are not submitted exclusively to the British Medical fournal this must be stated. For detailed instructions to authors see page 6 of the issue dated 3 January 1976.

Correspondence on editorial business should be addressed to the Editor, British Medical fournal, BMA House, Tavistock Square, London WC1H 9JR. Telephone: 01-387 4499. Telegrams: Aitiology, London WC1. Communications will not be acknowledged unless a stamped addressed postcard or an international reply coupon is enclosed.

Authors wanting reprints of their articles should notify the Publishing Manager, BMA House, Tavistock Square, WC1H 9JR, on receipt of proofs.

\section{(C) British Medical Journal 1976}

All Rights Reserved. No part of this publication may be reproduced, stored in a retrieval system, or transmitted, in any form or by any means, electronic, mechanical, photocopying, recording or otherwise, without the prior permission of the British Medical fournal. 